\title{
Assessing the Vulnerability of Farm Households in Yogyakarta to Risks Associated with Climate Change
}

\author{
Jangkung Handoyo Mulyo ${ }^{l}$, Arif Wahyu Widada, ${ }^{1,}$, Sugiyarto ${ }^{l}$, and Masyhuri ${ }^{1}$ \\ ${ }^{I}$ Department of Agricultural Socioeconomics, Faculty of Agriculture, Universitas Gadjah Mada, Indonesia
}

\begin{abstract}
Agriculture sustainability has been threatened by climate change. Climate change affects not only food production but also harms the social life of farm households. This paper assesses farmers' perceptions of climate change issues, the scale of its impact on farm households, and measures the sensitivity, adaptation strategies, and the livelihoods vulnerability of farm households in Yogyakarta. Two hundred and four farm households representing coastal and mountainous farm households were interviewed using a structured questionnaire. Descriptive analysis and the Livelihoods Vulnerability Index (LVI) methods are used to analyze data. The results show that most farm households have low awareness of the issue of climate change as well as low-scale exposure and sensitivity to climate change. Meanwhile, the level of adaptation strategies for coastal farm households is slightly higher (better) than mountainous farm households. Livelihoods vulnerability indexes reveal that agricultural households in coastal and mountainous areas are at a low level of vulnerability related to climate change.
\end{abstract}

\section{INTRODUCTION}

Living things on earth live with the help of heat and energy from the sun. At least 70 percent of sunlight reaches the earth's surface due to various shortwavelength spectrums. The outer layers of the atmosphere will deflect thirty percent of solar radiation directed to the planet. It will be absorbed both on land and in water. The heat from infrared radiation is absorbed by a gas known as a greenhouse gas. The term greenhouse gas is given because the gases in the atmosphere retain heat and also the greenhouse walls. Some gases in the atmosphere, including water vapor $\left(\mathrm{H}_{2} \mathrm{O}\right)$, carbon dioxide $\left(\mathrm{CO}_{2}\right)$, and methane $\left(\mathrm{CH}_{4}\right)$ will trap this radiation. These gases absorb and reflect the radiation waves emitted by the earth and cause the heat to be stored on the surface of the Earth [1].

Today there are a lot of climate changes that include changes in the water cycle, wind, and air, which causes changes in the water cycle by global warming. Climate change is caused by the presence of 'greenhouse gases' into the atmosphere. These gases accumulate in the atmosphere, which results in global warming - changes in parameters related to global climates such as temperature, rainfall, soil, and sea humidity levels. However, predictions on climate change are uncertain. There is no definitive cause of an increase in the concentration of greenhouse gases in the atmosphere and the unknown period [2].

Agriculture is an important sector to consider in terms of change. Climate change affects the agricultural sector. Climate change and climate variability are a phenomenon of climate anomalies that are of serious concern because they have a significant impact on the agriculture sector. Over the past 30 years, there have been several extreme climatic

\footnotetext{
Corresponding author: arif.w.widada@ugm.ac.id
}

conditions in Indonesia, characterized by the increasingly high frequency of climate variability [3]. The results of the FAO show that variability and climate change affect $11 \%$ of agricultural land in developing countries, which can reduce food production and reduce Gross Domestic Product (GDP) by $16 \%$ [4]. In the next 2080 , there will be a decline in the productivity of agricultural commodities in Indonesia between $15-25 \%$ due to global warming. If $\mathrm{CO}_{2}$ enrichment in the atmosphere is taken into account, the decrease in the productivity ranges from $5-15 \%$ of current production. Increased frequency of drought and flooding are projected to occur negatively affecting local crop production, especially in the subsistence sector in the lowlands [2,5].

Empirical results reveal there are farm households that are vulnerable to climate change and weather variability. Farmer households in other cities are also more sensitive in terms of adaptive capacity, taking into account the socio-demographic aspects, social networks, and household livelihoods. This result has implications for the initiation and implementation of climate change adaptation and household improvement projects by governments, donor agencies, and other related organizations [6]. Climate change has an impact on the continued development of most developing countries in Asia, including pressures on natural resources and the environment [7].

Analysis of the perception of climate change encourages a person or group to respond to perceived or not climate change. A person's viewpoint will be shaped by experience and indigenous knowledge about climate and the observed impacts of climate change. The majority of adults in all states believe that global 
warming is happening, ranging from lows of 54\% and $55 \%$ in West Virginia and Wyoming to highs of $75 \%$ and $81 \%$ in Hawaii and District of Columbia respectively $[7,8]$. The degree of the perceived impact of climate change essentially linked with farmers' adaptation practices toward the climate change's impact. The higher the impact of climate change, the farmers tend to have a higher adoption level of adaptation practices. In case of Indonesian farmers, the variables of higher education level, secure land tenure, the existence of irrigation infrastructure, and access to extension services downscale the degree of perceived impact of climate change [9].

Geographical patterns depend on certain beliefs, risk perceptions, policies, or questionable behavior. Many people in all countries believe that global warming is happening and carbon dioxide must be interpreted as a pollutant. But, not a few of them think that global warming is caused entirely by human activity. One way of adaptation for farmers is to change the planting date to focus on them when the rainfall and rain time vary [10].

The LVI is used to improve indicators of adaptive capacity that determine households, and intensive investigations are carried out in agricultural communities. The results of the calculations are used to restore livelihoods, move to categories, and increase the ability to adapt backward - education of household heads, agricultural land, non-agricultural income, and agriculture [11].

\section{RESEARCH METHODS}

\subsection{Identifying Farmers' Household Perceptions of Climate Change}

\subsubsection{Calculating the Magnitude of Farmers' Households Affected by Climate Change}

The first step taken is to standardize the values obtained from the results of field observations. This step is made to determine a large number of farm households affected by climate change. Standardization is essential before proceeding to the core calculation because there are unit differences in each of the subcomponents making up the main component. Standardization of the values obtained can be done by following the following equation [12]:

$$
\text { index } S_{a}=\frac{S_{a}-S_{\min }}{S_{\min } \max }
$$

Where:

IndexSa : index of Sa value obtained through calculation.
$\mathrm{Sa}$

: subcomponent values for the area a, obtained from the survey.

Smin : the minimum value of each subcomponent value displayed using data from both areas.

Smax : the minimum value of each sub-component value displayed using data from both areas.

After standardization, then determine the value of the main component. Determination of the value of the main components follows the following equation [12]:

$$
\operatorname{NDCV}_{\mathrm{a}}=\frac{\sum_{\mathrm{i}=1}^{\mathrm{n}} \text { indexs }_{\mathrm{a}}}{\mathrm{n}}
$$

Where:

NDCVa: the value of the main components for the area a, namely natural disasters and climate variability.

indexSa: index of the value of $\mathrm{Sa}$ obtained through calculations.

$\mathrm{N}$ : number of sub-components for each principal component counted.

After getting the value of the main components making up the exposure or the magnitude of the impact, the value of the exposure or the size of the impact can be determined by the following equation [12]:

Where:

$$
\mathrm{CF}_{\mathrm{Ea}}=\frac{\sum_{\mathrm{i}=1}^{\mathrm{n}} \mathrm{w}_{\mathrm{NDCV}}{ }^{*} \mathrm{NDCV}_{\mathrm{a}}}{\mathrm{w}_{\mathrm{NDCV}}}
$$

$\mathrm{CF}_{\mathrm{Ea}}$ : the value of exposure or magnitude of the impact of climate change based on IPCC formulation for the area a.

NDCVa: the major component values for the area a, namely natural disasters and climate variability.

$\mathrm{W}_{\mathrm{NDCV}}$ : the size of each major component specifically for natural disasters and climate variability.

The result of the equation above is obtained CFED value, which is an index to determine how large the household of farmers in an area exposed to or affected by climate change. The exposure index value ranges from 0 to 1 . Information on the index value of 0 means that households in the area are least affected by climate change. While the index value of 1 means that households in the area are the most affected by climate change. By comparing the exposure index values of the two regions, then it can be determined which areas are more affected by climate change.

\subsubsection{Calculate the Sensitivity of Farmers Households to Climate Change}

The second step is to standardize the values for each sub-component obtained from field observations. This step is used to determine the sensitivity of farm households to climate change. Standardization for the 
main sub-component values in particular for adaptive capacity can follow the following Equation (1) [12]:

After the second step is completed and the value is standardized, then the value of the main components making up the sensitivity can be determined, namely agriculture, food, and water. Determination of the value of these main components is obtained by entering the index value Sa into equation [12]:

$$
\mathrm{A}_{\mathrm{a}}, \mathrm{F}_{\mathrm{a}}, \mathrm{W}_{\mathrm{a}}=\frac{\sum_{\mathrm{i}=1}^{\mathrm{n}} \text { indexs }_{\mathrm{a}}}{\mathrm{n}}
$$

Where:

Aa: the value of the main component (Agriculture) for the area a.

Fa: the main component (Food) value for the area a.

Wa: the value of the main component (Water) for the area a.

indexSa: The standardized Sa value.

$\mathrm{n}$ : number of sub-components for each main component counted.

After obtaining the value of the main components of the sensitivity constituent, a calculation of the sensitivity value of farm households in climate change can be determined by the following equation [12]:

$$
\mathrm{CF}_{\mathrm{S}_{\mathrm{a}}}=\frac{\sum_{\mathrm{i}=1}^{\mathrm{n}} \mathrm{W}_{\mathrm{A}} \mathrm{A}_{\mathrm{a}} \mathrm{W}_{\mathrm{F}} \mathrm{F}_{\mathrm{a}} \mathrm{W}_{\mathrm{D}} \mathrm{D}_{\mathrm{a}}}{\mathrm{W}_{\mathrm{A}}+\mathrm{W}_{\mathrm{D}}+\mathrm{W}_{\mathrm{D}}}
$$

Where:

CFsa: sensitivity value based on IPCC formulation for the area a.

Aa, Fa, Da: Major component values for the area a, including agriculture, food, and water.

$\mathrm{W}_{\mathrm{A}}, \mathrm{W}_{\mathrm{F}}, \mathrm{W}_{\mathrm{D}}$ : the size of each major component of agriculture, food, and water.

CFsd: value is an index to determine how much sensitivity of farm households in an area to climate change. The adaptation ability index value ranges from 0 to 1 . The lowest value is an index value of 0 means that farm households in an area cannot adapt to climate change. While the index value of 1 means the highest value at which farm households in an area have excellent adaptability at climate change. From the comparison of the index value of the adaptability of the two regions, it can be determined which areas have better adaptability to climate change.

\subsubsection{Calculate the Magnitude of Farmer Household Adaptation Ability in Climate Change}

The third step is not much different from the previous step, which is to standardize the values on each subcomponent obtained from field observations. This step is carried out to determine the magnitude of the adaptability of farm households to climate change. Standardization of the values of the main sub- components of adaptability can follow the following Equation (1) [12]:

After the value is standardized, then the value of the main components that make up the adaptation ability can be determined, namely the social-population profile, livelihood strategies, and social networks. Determination of the value of these main components is obtained by entering the index value $\mathrm{Sa}$ into the equation [12]:

$$
\mathrm{C}_{\mathrm{a}}, \mathrm{E}_{\mathrm{a}}, \mathrm{I}_{\mathrm{a}}=\frac{\sum_{\mathrm{i}=1}^{\mathrm{n}} \text { index }_{\mathrm{a}}}{\mathrm{n}}
$$

Where:

$\mathrm{Ca} \quad$ : the value of the main component (Consumption) for the area a.

Ea : the value of the main component (Education) for the area a.

Ia : the value of the main component (Income) for the area a.

IndexSa : sd standardized value.

$\mathrm{N} \quad$ : number of sub-components for each main component counted.

After getting the value of the main components making up the adaptation ability, proceed to calculate the value of the adaptation ability of farm households in climate change can be determined by the following equation [12]:

$$
\mathrm{CF}_{\mathrm{A}_{\mathrm{a}}}=\frac{\sum_{\mathrm{i}=1}^{\mathrm{n}} \mathrm{W}_{\mathrm{C}} \mathrm{C}_{\mathrm{a}} \mathrm{W}_{\mathrm{E}} \mathrm{E}_{\mathrm{a}} \mathrm{W}_{\mathrm{I}} \mathrm{I}_{\mathrm{a}}}{\mathrm{W}_{\mathrm{C}}+\mathrm{W}_{\mathrm{E}}+\mathrm{W}_{\mathrm{I}}}
$$

Where:

CFAa: adaptability value based on IPCC formulation for the area a.

$\mathrm{Cd}, \mathrm{Ed}, \mathrm{Id}$ : the value of the main components for the area a, namely Consumption, Education, and Income respectively.

$\mathrm{W}_{\mathrm{C}}, \mathrm{W}_{\mathrm{E}}, \mathrm{W}_{\mathrm{I}}$ : the size of each major component for Consumption, Education, and Income.

The CFAd value is an index to determine how much the adaptability of farm households in an area to climate change. The index value of adaptation ability ranges from 0 to 1 . The index value of 0 means the lowest value where farm households in an area cannot adapt to climate change. While the value of 1 means the highest value at which farm households in an area have excellent adaptability at climate change. By comparing adaptation ability index values of the two regions, it can be determined which areas have better resilience to climate change.

\subsubsection{Calculating the Livelihoods Index of Farmers' Livelihoods on Climate Change}

The next step is to calculate the Livelihood Vulnerability Index (LVI) to determine the size of the adaptability of farm households to climate change 
(Hahn, 2009). After all the data making up the main components are standardized, then the LVI calculation can be done by following the equation as follows [12]:

$$
\operatorname{LVI}_{\mathrm{a}}=\frac{\sum_{\mathrm{i}=1}^{7} \mathrm{~W}_{\mathrm{M}_{\mathrm{i}}} \mathrm{M}_{\mathrm{d}_{\mathrm{i}}}}{\sum_{\mathrm{i}=1}^{7} \mathrm{~W}_{\mathrm{M}_{\mathrm{i}}}}
$$

$$
\mathrm{LVI}_{\mathrm{a}}=\frac{\mathrm{W}_{\mathrm{C}} \mathrm{C}_{\mathrm{a}}+\mathrm{W}_{\mathrm{E}} \mathrm{E}_{\mathrm{a}}+\mathrm{W}_{\mathrm{I}} \mathrm{I}_{\mathrm{a}}+\mathrm{W}_{\mathrm{A}} \mathrm{A}_{\mathrm{a}}+\mathrm{W}_{\mathrm{F}} \mathrm{F}_{\mathrm{a}}+\mathrm{W}_{\mathrm{W}} \mathrm{W}_{\mathrm{a}}+\mathrm{W}_{\mathrm{NDCV}} \mathrm{NDCV}_{\mathrm{a}}}{\mathrm{W}_{\mathrm{C}}+\mathrm{W}_{\mathrm{E}}+\mathrm{W}_{\mathrm{I}}+\mathrm{W}_{\mathrm{A}}+\mathrm{W}_{\mathrm{F}}+\mathrm{W}_{\mathrm{W}}+\mathrm{W}_{\mathrm{NDCV}}}
$$

Information:

LVIa: Index of livelihood vulnerability of farm households in climate change.

Md: $\quad$ value for each major component for an area d

Wmi: the value of each sub-component making up the main component.

$\mathrm{Cd}$ : the value of the main component for Consumption.

Ed: the value of the main components of Education.

Id: the value of the main component for Income.

Ad: the value of the main component of Agriculture.

Fd: the value of the main component for food.

Wd: main component value for water.

NDCVd: major component values for natural disasters and climate variability.

WC: the value of the main sub-component of consumption.

WE: the value of the main sub-component of Education.

WI: the value of the main sub-component of Income.

WA: the value of the main agricultural subcomponent.

WF: the value of the main sub-component of food.

WW: the value of the main sub-component of water. WNDCV: the value of major sub-components of natural disasters and climate variability.

The value of LVIa takes a value from 0 to 1 . A value of 0 means the least vulnerable means the condition of farm households that are very vulnerable to livelihood on climate change. While the value of 1 means the most vulnerable, namely the status of farm households with very life span in climate change. After the LVI value is known, we can compare which regions have farming households have greater livelihood vulnerability to climate change.

The next calculation is done by following the analysis carried out using a merger of LVIa counts with the framework compiled by the IPCC.

Table 1. Group of Indicators of Livelihoods Vulnerability Index [12]

\begin{tabular}{ll}
\hline Indicator Group $\left(\mathrm{CF}_{\mathrm{d}}\right)$ & Main Components $(\mathrm{M})$ \\
\hline Exposure & Natural disasters \\
& Climate variability
\end{tabular}

\begin{tabular}{ll} 
Sensitivity & Agriculture \\
& Food \\
& Water \\
Adaptive capacity & Consumption \\
& Education \\
& Income \\
\hline
\end{tabular}

The calculation is done by sorting on each component of the indicator. After determining the value of $\mathrm{CFEa}$ or $\mathrm{e}$ (exposure), CFAa or an (adaptability), and CFSa or s (sensitivity), the value of vulnerability can be determined by following the equation [11]

$$
\text { LVI-IPCC }_{\mathrm{a}}=\left(\mathrm{e}_{\mathrm{a}}-\mathrm{a}_{\mathrm{a}}\right) \cdot \mathrm{s}_{\mathrm{a}}
$$

Where:

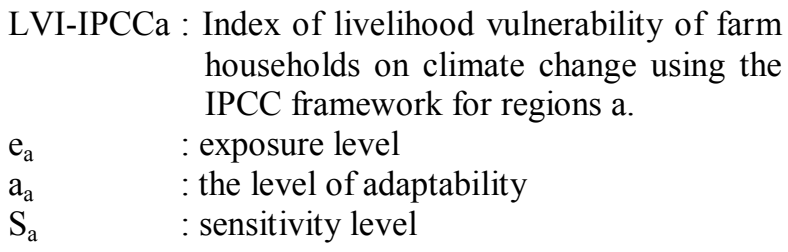

The livelihood vulnerability index (LVI) combined with the IPCC formula has a value ranging from -1 to 1 . The index value indicates the smaller the level of vulnerability, the more resistant the households. The index of -1 means the most resilient, which is the situation of farm households is excellent towards livelihoods related to climate change. And, when the value of +1 is called the most vulnerable, the position of farm households is very vulnerable to climate change. The best condition (LVI $=-1$ ) is reached when (i) the exposure is 0 , i.e. when there is no disaster or adverse impact caused by climate change, (ii) the adaptive capacity is 1 when households have an adaptation strategy and excellent adaptability in dealing with possible hazards and the harmful effects of climate change, and (iii) the sensitivity level is 1 , namely when farm households have awareness and knowledge as well as useful insights on climate change and disasters that may be caused by climate change [12].

\subsection{Research Locations and Samples}

The locations of the study are determined using a purposive sampling method that covered two areas in different agroecosystems, namely the coastal and mountainous area. From each agroecosystem, two locations are chosen purposively based on two criteria: (i) the area that has experienced/often experienced natural disasters related to climate change (floods, landslides, hurricanes, long drought, etc.) and (ii) areas that are generally safe/normal (not affected by 
disasters). A total of 204 farm households are selected randomly based on the data of Gapoktan (the Association of Farmers' Group).

\section{RESULTS AND DISCUSSION}

\subsection{Farmers' Perceptions of Agroecosystem Based Climate Change in Yogyakarta}

The results show that farmers' understanding of climate change issues varies between locations. Farmers are always dealing directly with the climate in their farming business activities. Studies and knowledge of climate change among farmers are still very few even though farmers in their lives often face global warming and in particular climate change. The following is knowledge of farmer households on climate change and global warming on mountainous and coastal agroecosystems presented in table 2 .

Table 2. Farmers' Awareness on Climate Change and Global Warming in the Mountainous and Coastal Agroecosystem in Yogyakarta.

\begin{tabular}{llllll}
\hline & & \multicolumn{2}{c}{ Global Warming } & \multicolumn{2}{l}{$\begin{array}{l}\text { Climate } \\
\text { Change }\end{array}$} \\
\cline { 3 - 6 } No. & Agroecosystem & Know & $\begin{array}{l}\text { Don't } \\
\text { Know }\end{array}$ & Know & $\begin{array}{l}\text { Don’t } \\
\text { Know } \\
\end{array}$ \\
& & $(\%)$ & $(\%)$ & $(\%)$ & $(\%)$ \\
\hline 1 & Mountainous & 22.79 & 77.21 & 22.06 & 77.94 \\
2 & Coastal & 33.82 & 66.18 & 30.88 & 69.12 \\
\hline
\end{tabular}

Source: Primary Data, 2018

Table 2 shows that both the area has a considerable percentage of people who don't know climate change and global warming. Most farm households are not aware of the phenomenon of climate change and global warming. Farmers do not understand well both terms because most of the farmers have a limited level of knowledge and lack access to information about the issues. The extension officers also do not provide adequate information related to climate change and global warming. In general, farmers in the coastal area slightly have a better knowledge about the climate change issue. This condition may be due to the location distance to the town (government offices and center of education). So that information dissemination occurs more quickly in the coastal area. Besides, farmer household members who are still in school and mastering technology significantly contribute to raising awareness about climate change and global warming and its effect on agricultural activities.

It is difficult to determine the start of the growing season, especially for rice as the main crop cultivated by farmers. It is because these plants need more water than other cultivated plants because the number of farmer and farmer households, in particular, is aware of increasingly erratic rain. The difficulty of determining the beginning of the growing season is realized and felt by farm households in both agroecosystems. Farmers in the mountainous area have a more significant percentage because almost all farmers depend on rain to determine the start of the growing season, especially rice as the main crop planted in the early rainy season which is planted in rain-fed rice fields, while farmers in the coastal area can still be helped by the presence of technical irrigation so that it still has the water needed at the beginning of rice planting and in making decisions determining the initial planting period even though most still find it increasingly challenging to decide on the start of the planting season caused by climate change, especially in Gunungkidul Regency as a representative of mountainous agroecosystems.

\subsection{Impacts of Climate Change on Agroecosystem Based Farmers in Yogyakarta}

Climate change has a significant impact on farm household farming activities. Uncertain rainfall and the determination of the beginning of the growing season which is increasingly challenging to determine will make it difficult for farmers to decide the planting period with commodities that are suitable for the season. Some obstacles that occur in the coastal region and the mountainous area are when planting rice and rain has not fallen, it will result in plants not growing correctly and reducing production. Another obstacle is when it is still felt the dry season and cultivates crops and vegetables such as peanuts and chili, and suddenly in the dry season, it rains which causes plants to rot and begin to be attacked by various diseases. Climate change that is not realized by farm households greatly disrupts their livelihoods from the agricultural sector because it affects materially.

Climate change has significantly had a significant impact on the livelihoods of farm households in both the coastal and mountainous areas. Climate change, especially irregular rainfall, has caused prolonged drought or prolonged rain, which has confused farmers in applying the growing calendar that farmers already have. Different topographical conditions between farm households in the coastal and mountainous areas have a different magnitude of impact on climate change. For coastal areas that rely more on rainwater as the primary source of water in farming activities, they will experience crop failure and drought both overall and especially for agricultural land that is larger than farm households in the mountainous area.

Measurement of the magnitude of the impact of climate change experienced by farm households based on the Exposure method can be measured from natural disasters and what is caused by natural disasters and 
climate variability in farm households [12]. Measurement of the components of exposure or the size of farm households affected by climate change can be seen in table 3 .

Table 3. The Magnitude of the Impact of Climate Change (Exposure) on Farmers' Households

\begin{tabular}{|c|c|c|c|}
\hline $\begin{array}{l}\text { Main } \\
\text { Components }\end{array}$ & $\begin{array}{l}\text { Sub } \\
\text { Component }\end{array}$ & Mountainous & Coastal \\
\hline \multirow{7}{*}{$\begin{array}{l}\text { Natural } \\
\text { disasters } \\
\text { and climate } \\
\text { variability }\end{array}$} & $\begin{array}{l}\text { Household } \\
\text { farmers know } \\
\text { climate } \\
\text { change }\end{array}$ & 0.29 & 0.31 \\
\hline & $\begin{array}{l}\text { Number of } \\
\text { flood events } \\
\text { in the last } \\
\text { three years }\end{array}$ & 0.96 & 1.00 \\
\hline & $\begin{array}{l}\text { Number of } \\
\text { drought } \\
\text { events in the } \\
\text { past three } \\
\text { years }\end{array}$ & 0.86 & 0.84 \\
\hline & $\begin{array}{l}\text { Number of } \\
\text { strong wind } \\
\text { events in the } \\
\text { last three } \\
\text { years }\end{array}$ & 0.22 & 0.60 \\
\hline & $\begin{array}{l}\text { Number of } \\
\text { landslide } \\
\text { events in the } \\
\text { past three } \\
\text { years }\end{array}$ & 0.01 & 0.03 \\
\hline & $\begin{array}{l}\text { Did not } \\
\text { receive a } \\
\text { warning }\end{array}$ & 0.49 & 0.49 \\
\hline & $\begin{array}{l}\text { have had a } \\
\text { physical } \\
\text { injury }\end{array}$ & 0.01 & 0.01 \\
\hline \multicolumn{2}{|c|}{ Exposure Index } & 0.19 & 0.20 \\
\hline
\end{tabular}

Based on Table 3 on the exposure criteria, it can be seen that the value of the Exposure Index of the two regions is relatively small because the area of study is not an area prone to natural disasters. Measurement of climate variability can be done as one component of the analysis of Exposure index values, namely frequent occurrence of prolonged drought, causing losses especially materially and is most felt by farm households in the mountainous area. The Mountainous area is more vulnerable compared to the Coastal area mainly due to the effects of more considerable prolonged drought. In the Mountainous area where more agricultural land in the form of rain-fed rice fields will experience a more significant impact on climate change, namely land that is getting drier and harder to cultivate. Dryland will also disrupt the cultivation of plants in the absorption of nutrients and soil nutrients for growth so that it can cause losses and disrupt the main livelihoods of farm households. Whereas in the Coastal region smaller affected by climate change, mainly when drought occurs because it has a better technical irrigation system so that the need for water for cultivation plants can still be fulfilled.

\subsection{Sensitivity of Farm Households Against Climate Change Based on Agroecosystems in Yogyakarta}

Table 4. The Magnitude of Farmers' Sensitivity to Climate Change

\begin{tabular}{|c|c|c|c|}
\hline $\begin{array}{l}\text { Main } \\
\text { Compo } \\
\text { nents }\end{array}$ & Sub Component & $\begin{array}{l}\text { Mountai } \\
\text { n-ous }\end{array}$ & $\begin{array}{l}\text { Coas } \\
\text { tal }\end{array}$ \\
\hline \multirow{4}{*}{$\begin{array}{l}\text { Agricul } \\
\text { ture }\end{array}$} & Land area cultivated & 0.08 & 0.06 \\
\hline & $\begin{array}{l}\text { Many plants are } \\
\text { cultivated in a year }\end{array}$ & 0.25 & 0.25 \\
\hline & $\begin{array}{l}\text { Income is only from } \\
\text { agriculture }\end{array}$ & 0.44 & 0.40 \\
\hline & Not raising cattle or fish & 0.39 & 0.38 \\
\hline \multirow{5}{*}{ Food } & $\begin{array}{l}\text { Food Does not have } \\
\text { food reserves until next } \\
\text { season }\end{array}$ & 0.43 & 0.35 \\
\hline & $\begin{array}{l}\text { Do not have food } \\
\text { reserves }\end{array}$ & 0.27 & 0.24 \\
\hline & $\begin{array}{l}\text { Do not have seed } \\
\text { reserves }\end{array}$ & 0.55 & 0.34 \\
\hline & $\begin{array}{l}\text { Food is not from } \\
\text { farming itself }\end{array}$ & 0.23 & 0.29 \\
\hline & $\begin{array}{l}\text { The average number of } \\
\text { months for food } \\
\text { difficulty }\end{array}$ & 0.13 & 0.08 \\
\hline \multirow{6}{*}{ Water } & $\begin{array}{l}\text { Water Have water } \\
\text { problems }\end{array}$ & 0.68 & 0.59 \\
\hline & $\begin{array}{l}\text { Natural water for } \\
\text { household }\end{array}$ & 0.63 & 0.79 \\
\hline & $\begin{array}{l}\text { Long to the water } \\
\text { source }\end{array}$ & 0.09 & 0.02 \\
\hline & Household water needs & 0.35 & 0.34 \\
\hline & $\begin{array}{l}\text { Distance between land } \\
\text { and water source }\end{array}$ & 0.09 & 0.02 \\
\hline & $\begin{array}{l}\text { The distance of the } \\
\text { house to the water } \\
\text { source }\end{array}$ & 0.21 & 0.01 \\
\hline \multicolumn{2}{|c|}{ Adaptation Capacity Index } & 0.32 & 0.28 \\
\hline
\end{tabular}

\subsection{Farmer Household Adaptation Strategies for Climate Change Based on Agroecosystems in Yogyakarta}

The ability of adaptation by farm households in both the Mountainous and Coastal regions is essential to reduce and deal with the negative impacts caused by climate change. Measurement of adaptability is done by determining the value of the Adaptation Ability index, which is measuring the social profile of the 
population, income, consumption, and education of farm households in both regions. The measurement results can be seen in table 5 .

Table 5. The Large Capability of Farm Household Adaptation Strategies for Climate Change

\begin{tabular}{|c|c|c|c|}
\hline $\begin{array}{l}\text { Main } \\
\text { Compo } \\
\text { nents }\end{array}$ & Sub Component & $\begin{array}{l}\text { Mountain } \\
\text { ous }\end{array}$ & Coastal \\
\hline \multirow{3}{*}{$\begin{array}{l}\text { Consum } \\
\text { ption }\end{array}$} & $\begin{array}{l}\text { Consumption of rice } \\
\text { per day }\end{array}$ & 0.35 & 0.27 \\
\hline & non-staple food & 0.12 & 0.03 \\
\hline & $\begin{array}{l}\text { Do not do a } \\
\text { combination of } \\
\text { consumption }\end{array}$ & 0.51 & 0.76 \\
\hline \multirow[t]{2}{*}{$\begin{array}{l}\text { Educati } \\
\text { on }\end{array}$} & $\begin{array}{l}\text { Head of household } \\
\text { under nine years } \\
\text { Number of household } \\
\text { members with low }\end{array}$ & 0.67 & 0.37 \\
\hline & education & 0.32 & 0.28 \\
\hline \multirow{4}{*}{ Income } & household income & 0.49 & 0.52 \\
\hline & $\begin{array}{l}\text { Do not have non- } \\
\text { agricultural income }\end{array}$ & 0.42 & 0.37 \\
\hline & There is a wander & 0.21 & 0.10 \\
\hline & $\begin{array}{l}\text { Number of household } \\
\text { members who went } \\
\text { abroad }\end{array}$ & 0.09 & 0.06 \\
\hline \multirow{3}{*}{$\begin{array}{l}\text { Socio- } \\
\text { Demogr } \\
\text { aphic } \\
\text { Profile }\end{array}$} & Female RT Head & 0.04 & 0.01 \\
\hline & $\begin{array}{l}\text { The age of the head } \\
\text { household }\end{array}$ & 0.47 & 0.45 \\
\hline & $\begin{array}{l}\text { Number of } \\
\text { unproductive people }\end{array}$ & 0.20 & 0.21 \\
\hline \multicolumn{2}{|c|}{ Adaptation Capacity Index } & 0.33 & 0.29 \\
\hline
\end{tabular}

\subsection{Vulnerability of Farmer Household Livelihoods Due to Climate Change Based on Agroecosystems in Yogyakarta}

Table 6. Vulnerability of Farmer Household Livelihoods Due to Climate Change Based on Agroecosystems in Yogyakarta

\begin{tabular}{lll}
\hline Component & Mountainous & Coastal \\
\hline $\begin{array}{l}\text { Natural Disasters and } \\
\text { Climate Variability }\end{array}$ & 0.192 & 0.202 \\
Consumption & 0.328 & 0.355 \\
Education & 0.497 & 0.322 \\
Income & 0.303 & 0.262 \\
Socio Demographic Profile & 0.236 & 0.224 \\
Agriculture & 0.289 & 0.274 \\
Food & 0.322 & 0.261 \\
Water & 0.339 & 0.294
\end{tabular}

Exposure Index

Adaptation Ability Index

Sensitivity Index

LVI d

LVI - IPCC

Source: Primary Data, 2018

$\begin{array}{ll}0.192 & 0.202 \\ 0.325 & 0.286 \\ 0.320 & 0.278 \\ 0.295 & 0.265 \\ -0.043 & -0.023\end{array}$

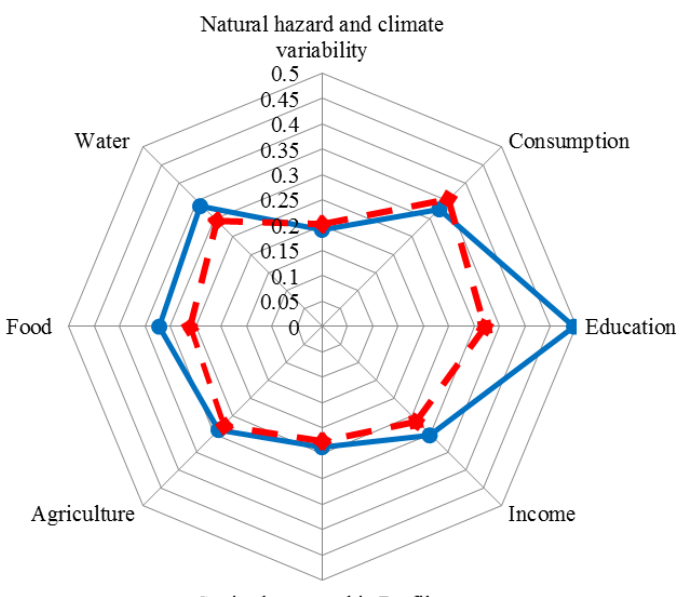

Socio-demographic Profile

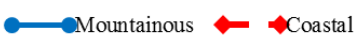

Figure 1. LVI Index of Each Main Component

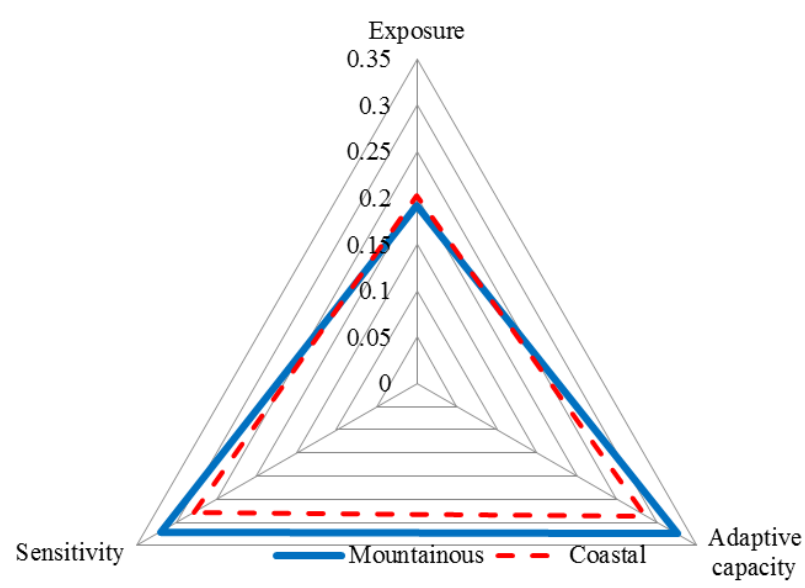

Figure 2. Mountainous and Coastal Vulnerability Triangle

From Figure 2, it can be seen that farm households in the mountainous area have a higher level of exposure, sensitivity, and adaptability to climate change. The picture with the lines that nearly coincide between the farm households in the mountainous and coastal areas shows the condition of livelihood vulnerability that is not much difference between the two regions. 
Higher adaptability compared to the magnitude of the impact of climate change felt by farm households in the mountainous area causes farm households in the mountainous area to be more resilient to climate change, which means that farmer households in the coastal region are more vulnerable to climate change. This statement is supported by the LVIa livelihood vulnerability index value for farm households in rural areas by 0.275 smaller than the LVIa livelihood index of 0.278 for farmer households in the Coastal area. The LVI values of the two regions are classified as moderate livelihood vulnerability, namely the LVI values of the two regions are between 0 and 0.5 . This statement is also supported by the value of LVI (livelihood vulnerability index) adjusted to the IPCC (Intergovernmental Panel on Climate Change) formulation. This formula is the LVI - IPCC value for farmer households in the Mountainous area of -0.021 , and the LVI - IPCC value for farmer households in the Coastal area amounting to -0.006 . This value also shows that farmer households in the coastal area in Bantul Regency have a higher livelihood vulnerability to climate change compared to farmer households in the mountainous area. The LVI - IPCC value for the two regions also shows that the two areas are at a moderate level of vulnerability in the middle of the interval between -1 to 1 .

\section{CONCLUSIONS AND RECOMMENDATIONS}

\subsection{Conclusions}

Farmers do not possess profound understanding of climate change and global warming, as well as lack of access to information about the issues related to climate change.

Farm households in both the area, mountainous and coastal, are exposed by the climate change at a low level of exposure. Farm households in the mountainous area have almost the same low-level sensitivity to climate change with coastal farm households. The coastal farm households possess a better adaptation strategy than those of the mountainous. The vulnerability of livelihoods of farm households to climate change in both types of agroecosystems is considered quite low because it has a better adaptation strategy than the perceived impact.

\subsection{Suggestions}

1. Improving the understanding among farmers household on climate change-related issues, including adaptation capacity, sensitivity, and the exposure of climate change.
2. Farm households must start concentrating more on diversifying livelihoods, especially in the nonagricultural sector.

3. Farmer households need to increase their knowledge and understanding related to climate change to be able to determine the best adaptation strategy with the help of the government and other stakeholders.

\section{BIBLIOGRAPHY}

1. BMKG. Meteorology Climatology and Geophysics Council. (Climate Change and Air Quality Information Book in Indonesia. Jakarta (2012)

2. C. Aydinalp, M.S. Cresser. The effects of global climate change on agriculture. Am Eurasian J. Agr. Envrion. Sci, 3 (2008)

3. Y. Apriyana, E. Susanti, Suciantini, F. Ramadhani, E. Surmaini. Analysis of the impact of climate change on food crop production on dry land and the design of the information system. Agricultural Informatics, 25 (2016)

4. FAO. "Impact of Climate Change and Diseases on Food Security and Proverty Reduction". Special event background document for the $31 \mathrm{st}$ session of the committee on world food security. Rome (2005)

5. W. R. Cline. Global Warming and Agriculture: Impact Estimates by Country (Washington: Center for Global Development and the Peterson Institute for International Economics) (2007)

6. D. T. Adua, J. K. M. Kuwornub, H. A. S. N. Sasakib. Application of livelihood vulnerability index in assessing smallholder maize farming households' vulnerability to climate change in Brong-Ahafo region of Ghana. Kasetsart Journal of Social Sciences, 39 (2018)

7. Howe, P. D., M. Mildenberger, J.R. Marlon, and A. Leiserowitz. Geographic variation in opinions on climate change at state and local scales in the USA. Nature Climate Change. Advance Online Publication (2015)

8. Z.A. Elum, D. M. Modise, and A. Marr. Farmer's perception of climate change and 
responsive strategies in three selected provinces of South Africa. Climate Risk Management 16 (2017)

9. Rondhi, M., A.F. Khasan, Y. Mori, and T. Kondo. Assessing the role of the perceived impact of climate change on national adaptation strategy: the case of rice farming in Indonesia. Land (2019) 8,81; doi :10.3390/land8050081

10. IPCC. Climate Change, Impacts, Adaptation and Vulnerability Contribution of Working Group II to the Fourth Assessment Report of the Intergovermental Panel on Climate Change (IPCC). M.L. Parry, O $>$ F Canziani. J.P Palutikof, P.J van der Linden and C.E. Hanson (Eds) Cambridge. University of Press. Cambridge. 200 pp (2007)

11. N.M. Sujakhu, S. Ranjitkar, R. R. Niraula, M. A. Salim, A. Nizami, D. Schmidt-Vogt \& J. $\mathrm{Xu}$. Determinants of livelihood vulnerability in farming communities in two sites in the Asian Highlands, Water International, 43, DOI: $\quad 10.1080 / 02508060.2017 .1416445$ (2018)

12. B.M. Hahn, A. M. Riederer, and S. O. Foster. The Livelihood Vulnerability Index: A Pragmatic Approach to Assessing Risks from Climate Vulnerability and Change - A Case Study in Mozambique. Global Environmental Change (2009) 